Krushinska Z. G., Yuzvenko T. Yu. Oncological pathology in type 2 diabetes patients and its effects on the effectiveness of the treatment of diabetes. Journal of Education, Health and Sport. 2019;9(11): 337-348. eISSN 2391-8306. DOI http://dx.doi.org/10.12775/JEHS.2019.09.11.032

https://apcz.umk.pl/czasopisma/index.php/JEHS/article/view/JEHS.2019.09.11.032

http://dx.doi.org/10.5281/zenodo.3628690

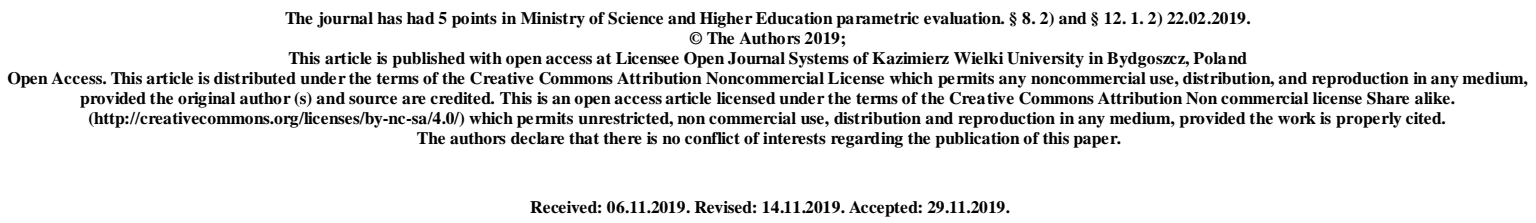

ONCOLOGICAL PATHOLOGY IN TYPE 2 DIABETES PATIENTS AND ITS EFFECTS ON THE EFFECTIVENESS OF THE TREATMENT OF DIABETES

\author{
Z. G. Krushinska, T. Yu. Yuzvenko
}

\title{
Ukrainian Center for Endocrine Surgery, Transplantation of Endocrine Organs and Tissues Ministry of Health of Ukraine
}

Zoya Krushinska - Senior Researcher, Department of Prevention, Treatment of Diabetes and its Complications, Honored Doctor of Ukraine, Ukrainian Center for Endocrine Surgery, transplantation of endocrine organs and tissues Ministry of Health of Ukraine, Kyiv. Address for correspondence: 01021, Kyiv, Klovsky Uzviz, 13a; contact phone - (044) 2543453 , 09867781 55, e-mail - sofi_75@bigmir.net, ORCID 0003-1888-7685.

Tatyana Yuzvenko - Deputy Director, PhD in Medicine, Ukrainian Center for Endocrine Surgery, transplantation of endocrine organs and tissues Ministry of Health of Ukraine, Kyiv. Address for correspondence: 01021, Kyiv, Klovsky Uzviz, 13a; contact phone - (044) 25432 23, e-mail - tatyuzvenko@gmail.com, ORCID 0003-4229-2075.

\section{Abstract}

Actuality of theme. The recognition of diabetes and cancer by global noncommunicable epidemics necessitates the need for research into the mechanisms behind the combination of diabetes and cancer, and the factors that lead to it.

The goal of the work. To study the structure and frequency of oncological pathology in patients with type 2 diabetes and its effect on the effectiveness of diabetes treatment.

Materials and methods. The study involved 2264 patients with type 2 diabetes (1186 men, 1078 women) who were treated at the Ukrainian Research Center for Endocrine Surgery, Endocrine Transplantation and Tissue of the Ministry of Health of Ukraine. The 
frequency and structure of oncological pathology in patients with type 2 diabetes, depending on the region of Ukraine, including the territories of military conflict, the place of residence of patients (countryside, city), duration of type 2 diabetes, BMI, HbA1c, medication tactics, macrovascular complications of diabetes (myocardial infarction (MI), stroke, diabetic foot syndrome (UDF). Medical and social factors were studied using a comparative analysis of the data obtained. Statistical processing of the obtained data was carried out using the program Statistika 10.0 (StatSoft).

Results and discussion. The incidence of cancer in patients with MI and stroke (7.12\% and $10.1 \%$, respectively) is higher than in patients without such complications $(6.46 \%$ and $6.05 \%$, respectively) with the opposite situation in patients with UDF - 2.3 times less than in patients without UDF (3.4\% vs. 7.7\%), and this indicator in patients with MI, stroke and without macrovascular complications is 1.8-3.0 times higher than in patients with UDF. The incidence of cancer is significantly higher when combined with 2 macrovascular complications. Almost $90 \%$ of cancers were diagnosed with type 2 diabetes.

The share of women with oncological pathology is twice as high as in men with a greater difference in patients from the Western region (13.8 times), BMI over $40 \mathrm{~kg} / \mathrm{m}^{2}(5.5$ times), HbA1c 9.1-10.0\% (4.6 times), duration of diabetes 11-15 years and more than 20 years (3.4 times and 3.9 times, respectively), Central region and duration of diabetes 16-20 years (3.3 times). The incidence of cancer in men ( $4.47 \%$ among all men) is higher in patients with MI and stroke, Eastern and Southern regions, duration of diabetes 6-10 years, BMI 30$34.9 \mathrm{~kg} / \mathrm{m}^{2}$ and $35-39.9 \mathrm{~kg} / \mathrm{m}^{2}, \mathrm{HbA} 1 \mathrm{c}$ up to $6.0 \%$ and $8.1-9.0 \%$ and in patients with insulin therapy, but less in patients with UDF, Western and Central regions, BMI 18.5-24.9 kg/m², $25-29.9 \mathrm{~kg} / \mathrm{m}^{2}$ and over $40 \mathrm{~kg} / \mathrm{m}^{2}$, newly diagnosed type 2 diabetes, duration of type 2 diabetes 11-15 years, 16-20 years and more than 20 years, HbA1c 8.1-9,\% and more than $10.0 \%$ and in patients on combination therapy. The incidence of oncologic pathology in women (8.81\% among all women) is higher in patients with MI, stroke, Western and Southern region, duration of diabetes mellitus type 11-15 years, BMI $35-39.9 \mathrm{~kg} / \mathrm{m}^{2}$ and over $40 \mathrm{~kg} / \mathrm{m}^{2}, \mathrm{HbA} 1 \mathrm{c}$ up to $6.0 \%$ and $8.1-9.0 \%$, but less in patients with UDF, Eastern region and territories of military conflict, duration of type 2 diabetes over 20 years, rural area, BMI 18.5$24.9 \mathrm{~kg} / \mathrm{m}^{2}, \mathrm{HbA} 1 \mathrm{c} 8.1-9, \%$ and more than $10.0 \%$ in patients with insulin therapy.

The leading place in the structure of oncologic pathology is occupied by thyroid cancer with a higher rate in patients with stroke, without macrovascular complications and lower rates in patients with MI and UDF and genital cancer with the opposite situation in the proportion of patients with such pathology. The incidence of breast and kidney cancer in 
patients with UDF is several times higher than in patients with MI, stroke and without macrovascular complications. In the structure of oncological pathology in men with MI, the first place occupy the prostate cancer and the cancer of the thyroid gland $(36.36 \%$ and $18.18 \%)$, with stroke - thyroid cancer $(33.33 \%)$, prostate, testes, colon and kidney $(16.67 \%$ each), with UDF - thyroid cancer, kidney cancer and lymphocytic leukemia (20.0\% each), and without macrovascular complications - thyroid cancer and gastric cancer $(62.5 \%$ and $12.5 \%$ respectively). Proportion of prostate, colon and kidney cancer in men with macrovascular complications is several times higher than in patients without such complications. In the structure of oncological pathology in women with MI and stroke, the first place is occupied by thyroid cancer (50.0\% and $57.14 \%$ respectively) and cervical cancer $(40.0 \%$ and $23.08 \%$ respectively), with UDF - breast and thyroid cancer (40.0\% and $20.0 \%$ respectively), and without macrovascular complications - thyroid cancer and adrenal cancer $(47.54 \%$ and $11.48 \%$ respectively). Thyroid cancer share in women with MI, stroke and without macrovascular complications more than twice as high as in patients with UDF with the opposite situation with breast cancer, whose proportion in the structure of cancer is more than four times higher in patients with UDF.

No case of gastric cancer in patients with MI, stroke and VTS with the same rate in patients without macrovascular complications (3,57-4,03\%). No cases of adrenal cancer in patients with MI, single cases in patients with stroke and VTS as opposed to high and equal rates in patients without macrovascular complications $(9,29-10,77 \%)$. No cases of lung and stomach cancers in men and women with macrovascular complications; for adrenal cancer in men with macrovascular complications and in women with MI; kidney cancer in women with macrovascular complications; colorectal cancer in women of all categories of patients.

Conclusions. The incidence of oncologic pathology in patients with type 2 diabetes has significant differences depending on the patient's sex, territory and place of residence, duration of diabetes, BMI, HbA1c, macrovascular complications and medication tactics. The incidence of cancer in patients with type 2 diabetes is not significantly influenced by HbA1c levels in patients of both sexes, BMI in men, and women's residence, but the patient's area of residence and macrovascular complications of type 2 diabetes in patients of both sexes, the duration of diabetes in men and BMI in women have a significant impact, moderate impact male habitat and duration of type 2 diabetes in women.

Keywords: type 2 diabetes; cancer; cancer; efficacy; medical factors; social factors. 
Introduction. A combination of type 2 diabetes and cancer as the most common noncommunicable diseases, leading to significant social and economic consequences for individuals, their families and, in general, national health systems, requires scientific research, in particular the study of the mechanisms underlying such a combination, and the factors that lead to it.

Goal. To study the structure and frequency of cancer oncology in patients with type 2 diabetes and its effect on the effectiveness of diabetes care.

Materials and methods. The study involved 2264 type 2 diabetes mellitus patients (1186 men and 1078 women) from all regions of Ukraine, who have been receiving medical care for the past five years in the Ukrainian Center for Endocrine Surgery, transplantation of endocrine organs and tissues of the Ministry of Health of Ukraine. Investigated frequency and structure of oncology pathology in patients with type 2 diabetes mellitus depending on the territory of residence of patients (Central, Northern, Southern, Western, Eastern Ukraine, Kyiv, military conflict territories), patients' places of residence (countryside, city), duration of type 2 diabetes, body mass index (BMI), glycated hemoglobin (HbAc), drug tactics and diagnosis myocardial infarction (MI), stroke, diabetic foot syndrome (UDF). Medical and social factors were studied using a comparative analysis of the data obtained. Statistical processing of the obtained data was carried out using the program Stats 10.0 (StatSoft).

Results and discussion. The study found that the incidence of cancer (table 1) in patients with MI and stroke (7.12\% and $10.1 \%$, respectively) exceeds rates in patients without MI and without stroke (6.46\% and $6.05 \%$, respectively) with the opposite situation in patients with UDF - 2.3 times less than in patients without UDF (3.4\% vs. 7.7\%), and the incidence of cancer in patients with MI, stroke and without macrovascular complications 1.8-3.0 times higher than in patients with UDF.

Table 1

The incidence of oncological pathology in patients with type 2 diabetes depending on macrovascular complications, $\mathrm{n}(\%)$

\begin{tabular}{|l|c|c|c|c|c|c|}
\hline \multirow{3}{*}{ Indicator } & \multicolumn{7}{|c|}{ Categories of patients } \\
\cline { 2 - 7 } & $\begin{array}{c}\text { with MI } \\
(\mathrm{n}=267)\end{array}$ & $\begin{array}{c}\text { without } \\
\text { MI } \\
(\mathrm{n}=1997)\end{array}$ & $\begin{array}{c}\text { with } \\
\text { stroke } \\
(\mathrm{n}=198)\end{array}$ & $\begin{array}{c}\text { without } \\
\text { stroke } \\
(\mathrm{n}=2066)\end{array}$ & $\begin{array}{c}\text { with UDF } \\
(\Pi=705)\end{array}$ & $\begin{array}{c}\text { without } \\
\text { UDF } \\
(\Pi=1559)\end{array}$ \\
\hline $\begin{array}{l}\text { Oncological } \\
\text { pathology }\end{array}$ & $\begin{array}{c}19 \\
(7,12)\end{array}$ & $\begin{array}{c}129 \\
(6,46)\end{array}$ & $\begin{array}{c}20 \\
(10,1)\end{array}$ & $\begin{array}{c}125 \\
(6,05)\end{array}$ & $\begin{array}{c}24 \\
(3,4)\end{array}$ & $\begin{array}{c}120 \\
(7,7)\end{array}$ \\
\hline
\end{tabular}

Moreover, the frequency of oncological pathology (table 2) in patients with a combination of MI and stroke (17.78\%) is 2.9 times higher than with a combination of SDS 
and stroke (6.98\%), 2.5 times higher than in all patients with MI (7.12\%) and with a combination of MI and SDS (6.15\%), 1.8 times higher than in all patients with stroke $(10.1 \%)$.

Table 2

The incidence of oncological pathology in patients with type 2 diabetes when diagnosing 2 macrovascular complications, $\mathbf{n}(\%)$

\begin{tabular}{|l|c|c|c|c|c|c|}
\hline \multirow{4}{*}{ Indicator } & \multicolumn{2}{|c|}{$\begin{array}{c}\text { among patients with MI } \\
(\mathrm{n}=267)\end{array}$} & \multicolumn{2}{c|}{$\begin{array}{c}\text { among patients with } \\
\text { troke }(\mathrm{n}=198)\end{array}$} & \multicolumn{2}{c|}{$\begin{array}{c}\text { among patients with } \\
\text { UDF }(\mathrm{n}=705)\end{array}$} \\
\cline { 2 - 7 } & $\begin{array}{c}\mathrm{MI}+ \\
\text { stroke } \\
(\mathrm{n}=45)\end{array}$ & $\begin{array}{c}\text { MI }+ \\
\mathrm{UDF} \\
(\mathrm{n}=130)\end{array}$ & $\begin{array}{c}\text { stroke }+ \\
\text { MI } \\
(\mathrm{n}=45)\end{array}$ & $\begin{array}{c}\text { stroke }+ \\
\text { UDF } \\
(\mathrm{n}=86)\end{array}$ & $\begin{array}{c}\text { UDF + } \\
\text { MI } \\
(\mathrm{n}=130)\end{array}$ & $\begin{array}{c}\text { UDF + } \\
\text { stroke } \\
(\mathrm{n}=86)\end{array}$ \\
\hline $\begin{array}{l}\text { Oncological } \\
\text { pathology }\end{array}$ & $8(17,78)$ & $8(6,15)$ & $8(17,78)$ & $6(6,98)$ & $8(6,15)$ & $6(6,98)$ \\
\hline
\end{tabular}

It should be noted that almost $90 \%$ of oncological diseases were diagnosed in patients with type 2 diabetes (with MI - 90.48\%, with stroke - 90.0\%, with UDF - 95.83\%, without MI - 93.67\%, without - stroke - 89.29\%, without UDF - 93.33\%).

Significant differences in the incidence of oncological pathology in men and women were found, depending on medical and socio-economic factors (table 3).

The incidence of cancer in men (4.47\% among all men studied) the same in patients without macrovascular complications, rural residents and city dwellers, higher in patients with MI and stroke, Eastern and Southern Ukraine, duration of diabetes mellitus type 6-10 years, BMI $30-34.9 \mathrm{~kg} / \mathrm{m}^{2}$ and $35-39.9 \mathrm{~kg} / \mathrm{m}^{2}$, HbA1c up to $6.0 \%$ and $8.1-9.0 \%$ and on insulin therapy, but less in patients with UDF, Western and Central Ukraine, BMI 18.5-24.9 kg/m², $25-29.9 \mathrm{~kg} / \mathrm{m}^{2}$ and more than $40 \mathrm{~kg} / \mathrm{m}^{2}$, in first-time identified patients with duration of diabetes mellitus type 11-15 years, 16-20 years and more than 20 years, HbA1c 8.1-9.0\% and more than $10.0 \%$ and on combination therapy.

At the same time, the incidence of cancer in women ( $8.81 \%$ among all women studied) the same in patients without macrovascular complications, on tablet drug therapy and combination therapy, higher in patients with MI and stroke, Western and Southern Ukraine, duration of diabetes mellitus type 11-15 years, BMI $35-39.9 \mathrm{~kg} / \mathrm{m}^{2}$ and over $40 \mathrm{~kg} / \mathrm{m}^{2}, \mathrm{HbA} 1 \mathrm{c}$ up to $6.0 \%$ and $8.1-9.0 \%$, but less in patients with UDF, Eastern Ukraine and the territories of military conflict, duration of type 2 diabetes over 20 years, rural area, BMI $18.5-24.9 \mathrm{~kg} / \mathrm{m}^{2}$, HbA1c $8.1-9.0 \%$ and more than $10.0 \%$ on insulin therapy. 
The incidence of oncological pathology in patients with type 2 diabetes depending on the patient's gender, medical and socio-economic factors, $\mathbf{n}(\%)$

\begin{tabular}{|c|c|c|c|c|c|c|c|}
\hline \multirow{2}{*}{$\begin{array}{l}\text { Gender } \\
\text { of the } \\
\text { patient }\end{array}$} & \multicolumn{7}{|c|}{ Medical and socio-economic factors effects on the incidence of cancer } \\
\hline & $\begin{array}{l}\text { Territory of } \\
\text { residence of } \\
\text { patients }\end{array}$ & \begin{tabular}{|l} 
Place of \\
residence \\
of patients
\end{tabular} & $\begin{array}{l}\text { Duration of } \\
\text { type } 2 \\
\text { diabetes }\end{array}$ & BMI & $\mathrm{HbA1c}$ & $\begin{array}{c}\text { Medication } \\
\text { tactics }\end{array}$ & $\begin{array}{c}\text { Macrovascula } \\
\mathrm{r} \\
\text { complications }\end{array}$ \\
\hline & $\begin{array}{l}\text { Central } \\
\text { Ukraine }\end{array}$ & $\begin{array}{c}\text { countrysi } \\
\text { de }\end{array}$ & $\begin{array}{c}\text { first } \\
\text { discovered }\end{array}$ & $\begin{array}{c}18,5-24,9 \\
\mathrm{~kg} / \mathrm{m}^{2}\end{array}$ & to $6,0 \%$ & $\begin{array}{c}\text { on pill } \\
\text { therapy }\end{array}$ & with MI \\
\hline men & $3(2,73)$ & $7(4,38)$ & $4(3,31)$ & $5(3,4)$ & $4(7,02)$ & $28(4,02)$ & $9(5,52)$ \\
\hline \multirow[t]{2}{*}{ women } & $8(8,89)$ & $13(7,93)$ & $7(8,54)$ & $6(4,8)$ & $6(20,0)$ & $50(8,99)$ & $10(9,62)$ \\
\hline & $\begin{array}{l}\text { Northern } \\
\text { Ukraine }\end{array}$ & city & $1-5$ years & $\begin{array}{l}25-29,9 \\
\mathrm{~kg} / \mathrm{m}^{2}\end{array}$ & $6,1-7,0 \%$ & $\begin{array}{l}\text { on insulin } \\
\text { therapy }\end{array}$ & with stroke \\
\hline men & $6(3,17)$ & $46(4,48)$ & $15(4,89)$ & $15(3,77)$ & $9(4,86)$ & $8(5,23)$ & $6(6,59)$ \\
\hline \multirow[t]{2}{*}{ women } & $14(6,48)$ & $82(8,97)$ & $20(8,51)$ & $25(8,9)$ & $9(8,65)$ & $11(7,53)$ & $14(13,08)$ \\
\hline & $\begin{array}{l}\text { Southern } \\
\text { Ukraine }\end{array}$ & & 6-10 years & $\begin{array}{l}30-34,9 \\
\mathrm{~kg} / \mathrm{m}^{2}\end{array}$ & $7,1-8,0 \%$ & $\begin{array}{c}\text { on } \\
\text { combination } \\
\text { therapy }\end{array}$ & with UDF \\
\hline men & $2(6,25)$ & & $21(6,03)$ & $17(5,23)$ & $9(4,41)$ & $11(3,54)$ & $14(3,13)$ \\
\hline \multirow[t]{2}{*}{ women } & $6(17,14)$ & & $27(8,91)$ & $26(8,87)$ & $14(8,05)$ & $30(8,47)$ & $10(3,89)$ \\
\hline & $\begin{array}{l}\text { Western } \\
\text { Ukraine }\end{array}$ & & 11-15 years & $\begin{array}{l}35-39,9 \\
\mathrm{~kg} / \mathrm{m}^{2}\end{array}$ & $8,1-9,0 \%$ & & $\begin{array}{l}\text { without MI, } \\
\text { stroke, UDF }\end{array}$ \\
\hline men & $1(1,85)$ & & $6(2,96)$ & $7(5,19)$ & $14(6,7)$ & & $32(4,96)$ \\
\hline \multirow[t]{2}{*}{ women } & $14(25,45)$ & & $21(10,1)$ & $20(12,5)$ & $23(11,56)$ & & $59(8,7)$ \\
\hline & $\begin{array}{l}\text { Eastern } \\
\text { Ukraine }\end{array}$ & & 16-20 years & \begin{tabular}{|c} 
more than \\
$40 \mathrm{~kg} / \mathrm{m}^{2}$
\end{tabular} & $9,1-10,0 \%$ & & \\
\hline men & $4(5,63)$ & & $3(2,4)$ & $1(1,89)$ & $3(1,58)$ & & \\
\hline \multirow[t]{2}{*}{ women } & $3(3,61)$ & & $12(7,95)$ & $10(10,42)$ & $12(7,27)$ & & \\
\hline & $\begin{array}{c}\text { the city of } \\
\text { Kyiv }\end{array}$ & & $\begin{array}{c}\text { more than } \\
20 \text { years }\end{array}$ & & $\begin{array}{c}\text { more than } \\
10,0 \%\end{array}$ & & \\
\hline men & $35(4,99)$ & & $1(1,47)$ & & $9(3,32)$ & & \\
\hline \multirow[t]{2}{*}{ women } & $43(7,57)$ & & $5(5,75)$ & & $25(7,35)$ & & \\
\hline & $\begin{array}{c}\text { territories of } \\
\text { military } \\
\text { conflict }\end{array}$ & & & & & & \\
\hline men & $3(4,29)$ & & & & & & \\
\hline \multirow[t]{2}{*}{ women } & $4(4,82)$ & & & & & & \\
\hline & \multicolumn{7}{|c|}{ Among all patients studied } \\
\hline men & & & & $53(4,47)$ & & & \\
\hline women & & & & $95(8,81)$ & & & \\
\hline
\end{tabular}

In this case, the proportion of women with cancer pathology in all the studied categories of patients (with the exception of patients with UDF and territories of military conflict with the same indicators) higher than in men (twice among all patients studied) with a greater difference in patients from Western Ukraine (13.8 times), BMI over $40 \mathrm{~kg} / \mathrm{m}^{2}(5.5$ times), HbA1c 9.1-10.0\% (4.6 times), duration of type 2 diabetes over 20 years and 11-15 
years (3.9 times and 3.4 times, respectively), Central Ukraine and the duration of diabetes mellitus type 16-20 years (3.3 times).

In the structure of oncological pathology (table 4), thyroid cancer with a higher incidence in stroke patients $(50.0 \%$ versus $41.43 \%$ in patients without stroke) occupies a leading place, and the incidence of such cancer in patients with MI and UDF $(33.33 \%$ and $20.0 \%$, respectively) is less than in patients without these complications (without $47.69 \%$ without MI, $50.81 \%$ without UDF). The second place is occupied by genital cancer, the incidence of which is higher in patients with MI and stroke (38.1\% and $25.0 \%$ respectively), and with UDF (12.0\%), on the contrary, less than in patients without macrovascular complications (without MI - 10.0\%, without stroke - 12.14\%, without UDF - 14.52\%).

Table 4

\section{Structure of oncological pathology in patients with type 2 diabetes}

depending on macrovascular complications, $\mathrm{n}(\%)$

\begin{tabular}{|l|c|c|c|c|c|c|}
\hline \multirow{1}{*}{$\begin{array}{c}\text { Oncological } \\
\text { pathology }\end{array}$} & \multicolumn{7}{|c|}{ Categories of patients } \\
\cline { 2 - 7 } & $\begin{array}{c}\text { with MI } \\
(\mathrm{n}=267)\end{array}$ & $\begin{array}{c}\text { without } \\
\text { MI } \\
(\mathrm{n}=1997)\end{array}$ & $\begin{array}{c}\text { with } \\
\text { stroke } \\
(\mathrm{n}=198)\end{array}$ & $\begin{array}{c}\text { without } \\
\text { stroke } \\
(\mathrm{n}=2066)\end{array}$ & $\begin{array}{c}\text { with UDF } \\
(\Pi=705)\end{array}$ & $\begin{array}{c}\text { without } \\
\text { UDF } \\
(\Pi=1559)\end{array}$ \\
\hline Thyroid cancer & $7(33,33)$ & $\begin{array}{c}62 \\
(47,69)\end{array}$ & $10(50,0)$ & $\begin{array}{c}58 \\
(41,43)\end{array}$ & $5(20,0)$ & $\begin{array}{c}63 \\
(50,81)\end{array}$ \\
\hline Genital Cancer & $8(38,1)$ & $13(10,0)$ & $5(25,0)$ & $\begin{array}{c}17 \\
(12,14)\end{array}$ & $3(12,0)$ & $18(14,52$ \\
)
\end{tabular}

Frequency of breast and kidney cancer in patients with UDF (16.0\% and $12.0 \%$, respectively) several times higher than in patients with MI (4.76\%), stroke (5.0\%) and without macrovascular complications (without MI $-6.15 \%$ and $4.62 \%$ respectively, without stroke $5.71 \%$ and $3.57 \%$ respectively, without SDS $-4.03 \%$ and $2.42 \%$ respectively).

No cases of gastric cancer have been identified in patients with MI, stroke and UDF with the same proportion of this pathology in patients without macrovascular complications (without MI - 3.85\%, without stroke - 3.57\%, without UDF - 4.03\%). No cases of adrenal cancer have been identified in patients with MI, one case in patients with stroke and UDF (5.0\% and $4.0 \%$, respectively) in contrast to diagnosing this pathology in every tenth patient 
without macrovascular complications (without MI - 10.77\%, without stroke $-9.29 \%$, without UDF - 9.68\%).

Table 5

Structure of oncological pathology in patients with type 2 diabetes

depending on the patient's gender and macrovascular complications, n (\%)

\begin{tabular}{|c|c|c|c|c|c|c|c|c|}
\hline \multirow{3}{*}{$\begin{array}{c}\text { Oncological } \\
\text { pathology }\end{array}$} & \multicolumn{8}{|c|}{ Categories of patients } \\
\hline & \multicolumn{2}{|c|}{ with MI } & \multicolumn{2}{|c|}{ with stroke } & \multicolumn{2}{|c|}{ with UDF } & \multicolumn{2}{|c|}{$\begin{array}{c}\text { without MI, stroke, } \\
\text { UDF }\end{array}$} \\
\hline & $\begin{array}{c}\text { men } \\
(\mathrm{n}=163)\end{array}$ & $\begin{array}{c}\text { women } \\
(\mathrm{n}=104)\end{array}$ & $\begin{array}{c}\text { men } \\
(\mathrm{n}=91)\end{array}$ & $\begin{array}{c}\text { women } \\
(\mathrm{n}=107)\end{array}$ & $\begin{array}{c}\text { men } \\
(n=448)\end{array}$ & $\begin{array}{c}\text { women } \\
(\mathrm{n}=257)\end{array}$ & $\begin{array}{c}\text { men } \\
(\mathrm{n}=645)\end{array}$ & $\begin{array}{c}\text { women } \\
(\mathrm{n}=678)\end{array}$ \\
\hline Thyroid cancer & $2(18,18)$ & $5(50,0)$ & $2(33,33)$ & $8(57,14)$ & $3(20,0)$ & $2(20,0)$ & $20(62,5)$ & $29(47,54)$ \\
\hline Breast cancer & 0 & $1(10,0)$ & 0 & $1(7,14)$ & 0 & $4(40,0)$ & 0 & $4(6,56)$ \\
\hline Cervical cancer & 0 & $4(40,0)$ & 0 & $3(23,08)$ & 0 & $1(10,0)$ & 0 & $5(8,2)$ \\
\hline Ovarian cancer & 0 & 0 & 0 & 0 & 0 & 0 & 0 & $1(1,64)$ \\
\hline $\begin{array}{l}\text { Cancer of the } \\
\text { vulva }\end{array}$ & 0 & 0 & 0 & 0 & 0 & 0 & 0 & $3(4,92)$ \\
\hline Prostate cancer & $4(36,36)$ & 0 & $1(16,67)$ & 0 & $2(13,33)$ & 0 & $1(3,13)$ & 0 \\
\hline $\begin{array}{l}\text { Testicular } \\
\text { cancer }\end{array}$ & 0 & 0 & $1(16,67)$ & 0 & 0 & 0 & 0 & 0 \\
\hline Adrenal cancer & 0 & 0 & 0 & $1(7,14)$ & 0 & $1(10,0)$ & $1(3,13)$ & $7(11,48)$ \\
\hline $\begin{array}{l}\text { Pancreatic } \\
\text { cancer }\end{array}$ & $1(9,09)$ & 0 & 0 & $1(7,14)$ & 0 & $1(10,0)$ & $1(3,13)$ & $3(4,92)$ \\
\hline Kidney cancer & $1(9,09)$ & 0 & $1(16,67)$ & 0 & $3(20,0)$ & 0 & $1(3,13)$ & $2(3,28)$ \\
\hline Bladder cancer & 0 & 0 & 0 & 0 & 0 & 0 & 0 & $2(3,28)$ \\
\hline Lung cancer & 0 & 0 & 0 & 0 & 0 & 0 & $1(3,13)$ & $2(3,28)$ \\
\hline Stomach cancer & 0 & 0 & 0 & 0 & 0 & 0 & $4(12,5)$ & $1(1,64)$ \\
\hline \begin{tabular}{|l|}
$\begin{array}{l}\text { Myeloma } \\
\text { disease }\end{array}$ \\
\end{tabular} & 0 & 0 & 0 & 0 & 0 & 0 & 0 & $1(1,64)$ \\
\hline $\begin{array}{l}\text { Lymphocytic } \\
\text { leukemia }\end{array}$ & 0 & 0 & 0 & 0 & $3(20,0)$ & 0 & 0 & $1(1,64)$ \\
\hline $\begin{array}{l}\text { Myeloma } \\
\text { leukemia }\end{array}$ & 0 & 0 & 0 & 0 & 0 & 0 & $1(3,13)$ & 0 \\
\hline Colon cancer & $1(9,09)$ & 0 & $1(16,67)$ & 0 & $1(6,67)$ & 0 & $1(3,13)$ & 0 \\
\hline Nose cancer & $1(9,09)$ & 0 & 0 & 0 & $1(6,67)$ & 0 & 0 & 0 \\
\hline Skin melanoma & $1(9,09)$ & 0 & 0 & 0 & $2(13,33)$ & 0 & 0 & 0 \\
\hline
\end{tabular}

At the same time, in the structure of cancer pathology in men with MI, the first place is occupied by prostate cancer and thyroid cancer (36.36\% and $18.18 \%)$, in men with stroke thyroid cancer (33.33\%), prostate cancer, testes, colon and kidney (16.67\% each), men with UDF - thyroid cancer, kidney cancer and lymphocytic leukemia (20.0\% each), in men without macrovascular complications - thyroid cancer and gastric cancer (62.5\% and 12.5\%, respectively). The share of prostate cancer, colon cancer and kidney cancer in men with macrovascular complications (with MI - 36.36\%, 9.09\% and 9.09\%, respectively, with stroke - $16.67 \%$, with UDF $-13.33 \%, 6.67 \%$ and $20.0 \%$ respectively) are several times higher than in patients without such complications (3.13\% each). 
And in the structure of oncological pathology in women with MI and stroke, the first place is occupied by thyroid cancer (50.0\% and $57.14 \%$ respectively) and cervical cancer (40.0\% and $23.08 \%$ respectively), women with UDF - breast cancer and thyroid cancer (40.0\% and $20.0 \%$ respectively), in women without macrovascular complications, thyroid cancer and adrenal cancer $(47.54 \%$ and $11.48 \%$, respectively). The incidence of thyroid cancer in women with MI, stroke and no macrovascular complications (50.0\%, 57.14\%, and $47.54 \%$, respectively) is significantly higher than in patients with UDF (20.0\%) with the opposite situation with higher incidence of breast cancer in patients with UDF (40.0\% versus $10.0 \%$ in patients with $\mathrm{MI}, 7.14 \%$ with stroke and $6.56 \%$ without macrovascular complications).

However, no cases of lung and gastric cancer have been reported in men and women with macrovascular complications; adrenal cancer in men with macrovascular complications and women with MI; kidney cancer in women with macrovascular complications; colon cancer in women of all categories of patients.

The study found no effect of cancer on the efficacy of type 2 diabetes, and the average HbA1c level corresponds to diabetes decompensation (tables 6, 7, 8).

Table 6

Average HbA1c in patients with type 2 diabetes mellitus depending on macrovascular complications, \%

\begin{tabular}{|l|c|c|c|c|c|c|}
\hline \multicolumn{1}{|c|}{ Indicator } & \multicolumn{6}{|c|}{ Categories of patients } \\
\cline { 2 - 7 } & $\begin{array}{c}\text { with MI } \\
(\mathrm{n}=267)\end{array}$ & $\begin{array}{c}\text { without } \\
\text { MI } \\
(\mathrm{n}=1997)\end{array}$ & $\begin{array}{c}\text { with } \\
\text { stroke } \\
(\mathrm{n}=198)\end{array}$ & $\begin{array}{c}\text { without } \\
\text { stroke } \\
(\mathrm{n}=2066)\end{array}$ & $\begin{array}{c}\text { with UDF } \\
(\Pi=705)\end{array}$ & $\begin{array}{c}\text { without } \\
\text { UDF } \\
(\Pi=1559)\end{array}$ \\
\hline $\begin{array}{l}\text { The average } \\
\text { HbA1c in the } \\
\text { whole group }\end{array}$ & $9,09 \pm 2,03$ & $9,03 \pm 2,06$ & $8,85 \pm 1,95$ & $9,05 \pm 2,06$ & $8,9 \pm 1,96$ & $9,09 \pm 2,1$ \\
\hline $\begin{array}{l}\text { Average HbA1c } \\
\text { in patients with } \\
\text { cancer }\end{array}$ & 8,84 & $8,79 \pm 2,01$ & 8,36 & $8,85 \pm 2,07$ & 8,45 & $8,82 \pm 2,09$ \\
{$[7,7 ; 9,2]$} & & {$[7,45 ;$} & & & & \\
\hline
\end{tabular}

Table 7

Average HbA1c in women with type 2 diabetes, \%

\begin{tabular}{|l|c|c|c|c|}
\hline \multirow{2}{*}{ Indicator } & \multicolumn{4}{|c|}{ Categories of patients } \\
\cline { 2 - 5 } & $\begin{array}{c}\text { with MI } \\
(\mathrm{n}=104)\end{array}$ & $\begin{array}{c}\text { with stroke } \\
(\mathrm{n}=107)\end{array}$ & $\begin{array}{c}\text { with UDF } \\
(\mathrm{n}=257)\end{array}$ & $\begin{array}{c}\text { without MI, } \\
\text { stroke, UDF } \\
(\mathrm{n}=678)\end{array}$ \\
\hline $\begin{array}{l}\text { The average HbA1c in } \\
\text { the whole group }\end{array}$ & $9,31 \pm 2,12$ & $9,03 \pm 2,06$ & $9,23 \pm 2,02$ & $9,33 \pm 2,08$ \\
\hline $\begin{array}{l}\text { Average HbA1c in } \\
\text { patients with cancer }\end{array}$ & $\begin{array}{c}9,33 \\
{[8,1 ; 9,2]}\end{array}$ & $\begin{array}{c}8,91 \\
{[8,1 ; 9,2]}\end{array}$ & $\begin{array}{c}9,12 \\
{[8,1 ; 10,4]}\end{array}$ & $8,77 \pm 2,0$ \\
\hline
\end{tabular}


Average HbA1c in men with type 2 diabetes, $\%$

\begin{tabular}{|l|c|c|c|c|}
\hline \multirow{2}{*}{ Indicator } & \multicolumn{4}{|c|}{ Categories of patients } \\
\cline { 2 - 5 } & $\begin{array}{c}\text { with MI } \\
(\mathrm{n}=163)\end{array}$ & $\begin{array}{c}\text { with stroke } \\
(\mathrm{n}=91)\end{array}$ & $\begin{array}{c}\text { with UDF } \\
(\mathrm{n}=448)\end{array}$ & $\begin{array}{c}\text { without MI, } \\
\text { stroke, UDF } \\
(\mathrm{n}=645)\end{array}$ \\
\hline $\begin{array}{l}\text { The average HbA1c in } \\
\text { the whole group }\end{array}$ & $8,94 \pm 1,95$ & $8,63 \pm 1,78$ & $8,71 \pm 1,91$ & $8,86 \pm 2,17$ \\
\hline $\begin{array}{l}\text { Average HbA1c in } \\
\text { patients with cancer }\end{array}$ & 8,23 & 7,14 & 7,98 & 8,4 \\
{$[7,45 ; 9,15]$} & {$[6,7 ; 7,7]$} & {$[7,3 ; 8,7]$} & {$[6,9 ; 9,0]$} \\
\hline
\end{tabular}

\section{Conclusions:}

1. The incidence of cancer in patients with type 2 diabetes has significant differences depending on the patient's gender, territory and place of residence of the patient, the duration of diabetes, body mass index, glycated hemoglobin, macrovascular complications and drug tactics.

2. The incidence of cancer in patients with type 2 diabetes is not significantly influenced by the level of glycated hemoglobin in patients of both sexes, body mass index for men, place of residence for women, but have a significant impact - patient's area of residence, myocardial infarction, stroke and diabetic foot syndrome in patients of both sexes, duration of type 2 diabetes in men, body mass index in women, moderate impact - male habitat and duration of type 2 diabetes in women.

3. Cancer has no effect on the effectiveness of treatment for type 2 diabetes.

4. Structure and frequency of oncological pathology in patients with type 2 diabetes requires a multidisciplinary approach to their prevention and diagnosis with the involvement of many interested professionals, what can not be achieved when the patient is managed by a family doctor.

5. Need to take into account the impact of medical and socio-economic factors on the development of cancer in patients with type 2 diabetes.

6. Further research is needed to study the mechanisms, primarily the genetic and hormonal underlying:

1) gender differences in type 2 diabetes mellitus and cancer, in particular:

significantly higher incidence of cancer in women with type 2 diabetes;

significantly higher incidence of prostate cancer, colon and kidney cancer in men with type 2 diabetes with macrovascular complications; 
no case of lung cancer and gastric cancer in patients with type 2 diabetes mellitus with macrovascular complications, adrenal cancer in men with type 2 diabetes with macrovascular complications and in women with type 2 diabetes and myocardial infarction, kidney cancer in women with type 2 diabetes and macrovascular complications, colon cancer in women with type 2 diabetes;

2) the differences in the frequency and structure of cancer oncology in patients with type 2 diabetes with macrovascular complications, in particular, significantly lower incidence of oncological pathology in patients with type 2 diabetes mellitus with diabetic foot syndrome; higher incidence of oncologic pathology in patients with type 2 diabetes with stroke, especially when combined with MI and stroke; higher incidence of breast and kidney cancer in women with type 2 diabetes with diabetic foot syndrome.

\section{References:}

1. Zheng Y, Ley SH, Hu FB. Global aetiology and epidemiology of type 2 diabetes mellitus and its complications. Nat Rev Endocrinol. 2018 Feb;14(2):88-98. doi: 10.1038/nrendo.2017.151.

2. International Diabetes Federation. IDF Diabetes Atlas, 8th ed. Brussels: IDF, 2017.

3. American Chemical Society (2019) How diabetes can increase cancer risk: DNA damaged by high blood sugar. ScienceDaily, Aug. 25.

4. Toshiaki Ohkuma, Sanne A. E. Peters, Mark Woodward. Sex differences in the association between diabetes and cancer: a systematic review and meta-analysis of 121 cohorts including 20 million individuals and one million events. Diabetologia, 2018; DOI: 10.1007/s00125-018-4664-5.

5. Fitzmaurice C, Allen C, Barber RM et al (2017) Global, regional, and national cancer incidence, mortality, years of life lost, years lived with disability, and disabilityadjusted life-years for 32 cancer groups, 1990 to 2015: a systematic analysis for the global burden of disease study. JAMA Oncol 3: 524-548.

6. Noto H, Tsujimoto T, Sasazuki T, Noda M (2011) Significantly increased risk of cancer in patients with diabetes mellitus: a systematic review and meta-analysis. Endocr Pract 17:616-628.

7. Abe R, Yamagishi S (2008) AGE-RAGE system and carcinogenesis. Curr Pharm Des 14:940-945.

8. Shikata K, Ninomiya T, Kiyohara Y. Diabetes mellitus and cancer risk: review of the epidemiological evidence. Cancer Sci. 2013 Jan;104(1): 9-14. doi: 10.1111/cas.12043. 
9. Gadi Shlomai, Brian Neel, Derek LeRoith, and Emily Jane Gallagher. Type 2 Diabetes Mellitus and Cancer: The Role of Pharmacotherapy. J Clin Oncol. 2016 Dec 10; 34(35): 4261-4269. Published online 2016 Nov 7. doi: 10.1200/JCO.2016.67.4044.

10. Global status report on noncommunicable diseases 2014. WHO/NMH/NVI/15.1 ISBN: 978924 156485 4: 298.

\section{All patients who participated in the study signed informed consent.}

There is no conflict of interest.

Source of funding: implementation of scientific topics - state budget, publication of gender - private individuals.

Participation of the authors: the concept of researching, collecting and processing materials, analyzing data, writing text - Z.G. Kruszynska, article concept, data analysis T.Yu. Yuzvenko. 